\title{
PERBANDINGAN KADAR NATRIUM SERUM SEBELUM DAN SESUDAH AKTIVITAS FISIK INTENSITAS BERAT
}

\author{
${ }^{1}$ Linda J. A. Montung \\ ${ }^{2}$ Michaela E. Paruntu \\ ${ }^{2}$ Murniati Tiho
}

\author{
${ }^{1}$ Kandidat Skripsi Fakultas Kedokteran Universitas Sam Ratulangi Manado \\ ${ }^{2}$ Bagian Biokimia Fakultas Kedokteran Universitas Sam Ratulangi Manado \\ Email: lmontung11_009@yahoo.com
}

\begin{abstract}
Sodium is the main cation within the extracellular fluid. During vigorous physical activity transpiration occurs resulting in elevation of sodium concentration in extracellular fluid if there is not enough fluid intake. This study aimed to obtain the difference between the blood serum sodium level before and after the vigorous physical activity. This was an experimental study with one group pretest and posttest design. Samples were obtained by using simple random sampling. There were 21 male medical students evaluated their blood serum sodium level. The mean of blood serum sodium level before the physical activity was $140.62 \mathrm{mEq} / \mathrm{L}$ and after the physical activity was $143.24 \mathrm{mEq} / \mathrm{L}$. The paired sample t-test showed that there was a significant correlation between the physical activity and the blood serum sodium ( $\mathrm{p}=0.005)$. Conclusion: There was a difference between the blood serum sodium levels before and after vigorous physical activity.
\end{abstract}

Keywords: serum sodium level, vigorous physical activity

\begin{abstract}
Abstrak: Natrium adalah kation utama dalam cairan ekstrasel. Ketika melakukan aktivitas fisik berat terjadi pengeluaran keringat. Jika tidak diimbangi dengan asupan cairan yang cukup dapat menyebabkan terjadinya peningkatan konsentrasi natrium dalam cairan ekstrasel. Penelitian ini bertujuan untuk mengetahui perbedaan antara kadar natrium serum darah sebelum dan sesudah aktivitas fisik berat. Penelitian ini menggunakan metode eksperimental dengan one group pretest and posttest design. Sampel diperoleh dengan metode simple random sampling. Sejumlah 21 mahasiswa Fakultas Kedokteran Unsrat Manado dievaluasi untuk menentukan kadar natrium serum darah. Rerata kadar natrium serum darah sebelum aktivitas fisik 140,62 mEq/L dan sesudah aktivitas fisik 143,24 mEq/L. Uji sample t-test menunjukkan korelasi bermakna antara aktivitas fisik dan kadar natrium serum darah ( $\mathrm{p}=$ 0,005). Simpulan: Terdapat perbedaan kadar natrium serum darah sebelum dan sesudah aktivitas fisik berat.
\end{abstract}

Kata kunci: kadar natrium serum, aktivitas fisik berat

Latihan fisik pada umumnya merupakan gabungan dari sistim anaerobik dan aerobik tetapi porsi kedua sistim tersebut tergantung pada cabang olahraganya. Untuk cabang olahraga yang menuntut aktivitas fisik dengan intensitas tinggi dengan waktu relatif singkat, contoh pada latihan maksimal lari sprint $400 \mathrm{~m}$, sistim energi predominannya ialah anaerobik. Sebaliknya, pada cabang olahraga yang menuntut aktivitas fisik dengan intensitas rendah dan berlangsung relatif lama, contoh pada latihan submaksimal jogging $1600 \mathrm{~m}$, sistim energi predominannya ialah aerobik. $^{1}$

Selama berolahraga atau melakukan 
latihan fisik, terjadi peningkatan produksi panas dari proses metabolisme dan kontraksi otot. Akibatnya, air yang berada di dalam sirkulasi aliran darah akan menyerap panas dan mengeluarkannya melalui keringat. Pengeluaran keringat yang berlebihan jika tidak diimbangi dengan konsumsi cairan yang cukup dapat menyebabkan terjadinya peningkatan konsentrasi elektrolit, termasuk natrium di dalam cairan ekstrasel. ${ }^{2}$

Kandungan natrium tubuh total seorang pria dengan berat rata-rata $70 \mathrm{~kg}$ kira-kira sebesar $3.700 \mathrm{mmol}$, 75\% diantaranya dapat tergantikan. Seperempat bagian dari natrium tubuh tersebut dikatakan tidak tergantikan, yang artinya natrium tersebut tergabung di dalam jaringan, seperti tulang, dan memiliki laju pergantian yang rendah. Sebagian besar natrium yang tergantikan berada dalam cairan ekstrasel. Dalam cairan ekstrasel, yang terdiri dari plasma dan cairan interstisial, kadar natrium diatur dengan ketat pada konsentrasi $140 \mathrm{mmol} / \mathrm{L} .^{3}$

Peningkatan konsentrasi natrium ekstrasel terjadi akibat pengeluaran air dari plasma darah ke permukaan kulit melalui kelenjar keringat, sehingga terjadi pemekatan natrium. ${ }^{4}$ Peningkatan konsentrasi natrium plasma lebih dari $148 \mathrm{mmol}$ dengan osmolalitas plasma lebih dari 295 $\mathrm{mOsm} / \mathrm{kg}$ dinamakan hipernatremia. Gambaran klinis hipernatremia mencakup peningkatan rasa haus, urin sedikit dan pekat, serta gangguan pada fungsi susunan saraf pusat meliputi penurunan refleks, kejang, dan koma. ${ }^{5}$

Keringat berlebihan dapat menyebabkan kehilangan air, dan elektrolit, terutama natrium dan klorida. ${ }^{3}$ Hiponatremia terjadi bila konsentrasi natrium plasma kurang dari 135 mmol dengan osmolalitas plasma kurang dari $280 \mathrm{mOsm} / \mathrm{kg}$. Hiponatremia ditandai oleh gangguan susunan saraf pusat termasuk konfusi, depresi, sakit kepala, stupor, dan koma serta keluhan pencernaan berupa kram, diare, dan muntah. ${ }^{5}$

Penelitian Wadud tahun 2013 menunjukkan bahwa latihan fisik aerobik dan latihan fisik anaerobik yang masing- masing dilakukan oleh 11 orang mahasiswa pendidikan olahraga, ternyata meningkatkan kadar natrium darah sesudah melakukan masing-masing latihan dari kedua latihan tersebut. ${ }^{4}$ Penelitian lainnya oleh Wahyudi et al. memaparkan hasil bahwa sebelum dan sesudah latihan fisik didapatkan penurunan yang bermakna dari rerata kadar natrium pada kelompok plasebo dan peningkatan yang bermakna kadar natrium pada kelompok yang minum glukosa. ${ }^{6}$

\section{METODE PENELITIAN}

Penelitian ini menggunakan metode eksperimental dengan desain penelitian one group pre-test and post-test. Subjek penelitian yaitu mahasiswa Fakultas Kedokteran Universitas Sam Ratulangi Program Studi Pendidikan Dokter Umum angkatan 2011 dengan jenis kelamin lakilaki. Permainan futsal dilakukan 2 x 20 menit dengan istirahat selama 10 menit. Pengambilan darah dilakukan 2 kali yaitu sebelum dan sesudah aktivitas fisik bermain futsal.

Penelitian ini dilaksanakan pada bulan September 2014 - Januari 2015 di lapangan futsal Megamas, kawasan Boulevard Manado dan pemeriksaan darah dilakukan di laboratorium Prodia. Variabel bebas yaitu aktivitas fisik intensitas berat dan variabel terikatnya yaitu kadar natrium darah. Data hasil penelitian dianalisis dengan menggunakan paired t-test.

\section{HASIL PENELITIAN}

Responden penelitian ini yaitu 21 mahasiswa Fakultas kedokteran Unsrat Manado. Distribusi responden berdasarkan usia diperoleh 10 orang $(47,6 \%)$ berusia 20 tahun, 8 orang $(38,1 \%)$ berusia 21 tahun, dan 3 orang (14,3\%) berusia 22 tahun.

Tabel 1. Distribusi Berdasarkan Usia

\begin{tabular}{ccc}
\hline Usia & Jumlah & $\mathbf{( \% )}$ \\
\hline 20 & 10 & 47,6 \\
21 & 8 & 38,1 \\
22 & 3 & 14,3 \\
Jumlah & 21 & 100 \\
\hline
\end{tabular}


Hasi pemeriksaan kadar natrium serum sebelum aktivitas fisik mendapatkan nilai maksimum $144 \mathrm{mEq} / \mathrm{L}$, minimum 138 $\mathrm{mEq} / \mathrm{L}$, median $141 \mathrm{mEq} / \mathrm{L}$, rerata 140 $\mathrm{mEq} / \mathrm{L}$ dengan standar deviasi 1,284 . Hasil pemeriksaan kadar natrium serum sesudah aktivitas fisik mendapatkan nilai maksimum $155 \mathrm{mEq} / \mathrm{L}$, minimum 135 $\mathrm{mEq} / \mathrm{L}$, median $143 \mathrm{mEq} / \mathrm{L}$, rerata 143 $\mathrm{mEq} / \mathrm{L}$ dengan standar deviasi 4,312.

Tabel 2. Pengolahan Data Univariat

\begin{tabular}{ccc}
\hline & Sebelum & Sesudah \\
\hline Mean & 140 & 143 \\
Standar Deviasi & 1,248 & 4,312 \\
Median & 141 & 143 \\
Minimal & 138 & 135 \\
Maksimal & 144 & 155 \\
\hline
\end{tabular}

Hasil pemeriksaan natrium serum dianalisis menggunakan uji normalitas Shapiro-Wilk dengan hasil kadar natrium serum sebelum dan sesudah aktivitas fisik intensitas berat berdistribusi normal. Uji t berpasangan dengan tingkat signifikan $\mathrm{p}<$ 0,005 memperoleh hasil $\mathrm{p}=0,005$.

Tabel 3. Distribusi Rata-Rata Kadar Natrium Serum Sebelum dan Sesudah Aktivitas Fisik Intensitas Berat

\begin{tabular}{cccccc}
\hline Variabel & Mean & $\begin{array}{c}\text { Standar } \\
\text { deviasi }\end{array}$ & $\begin{array}{c}\text { Standar } \\
\text { Error }\end{array}$ & $\begin{array}{c}\mathrm{p} \\
\text { value }\end{array}$ & $\mathrm{N}$ \\
\hline $\begin{array}{c}\text { Kadar } \\
\text { natrium } \\
\text { Pengukuran } \\
\text { I }\end{array}$ & 140,62 & 1,284 &, 280 & & \\
$\begin{array}{c}\text { Pengukuran } \\
\text { II }\end{array}$ & 143,24 & 4,312 &, 941 & & \\
\hline
\end{tabular}

Hasil uji ini menolak H1 dan menerima H0 yaitu tidak terdapat perbedaan kadar natrium serum sebelum dan sesudah aktivitas fisik intensitas berat.

\section{BAHASAN}

Dari hasil penelitian kadar natrium serum pada mahasiswa Fakultas Kedokteran Universitas Sam Ratulangi angkatan 2011 yang melakukan permainan futsal 2 x 20 menit dengan istirahat selama 10 menit didapatkan data seluruh responden memiliki kadar natrium normal sebelum melakukan aktivitas fisik intensitas berat tetapi sesudah melakukan aktivitas fisik intensitas berat terdapat sebagian responden mengalami peningkatan kadar natrium. Lesar ${ }^{7}$ meneliti mahasiswa Fakultas Kedokteran Universitas Sam Ratulangi angkatan 2010, dan mendapatkan dari 30 responden, sebanyak 20 responden yang mengalami peningkatan kadar natrium sesudah melakukan latihan fisik intensitas ringan.

Peningkatan kadar natrium sesudah latihan fisik pada penelitian ini sejalan dengan hasil penelitian Wadud $^{4}$ terhadap mahasiswa pendidikan olahraga dengan hasil terdapat peningkatan kadar natrium setelah respondennya melakukan aktivitas fisik aerobik dan anaerobik.

Penelitian yang dilakukan oleh Wahyudi et $\mathrm{al}^{6}$ terhadap anak Sekolah Lanjutan Tingkat Pertama (SLTP) mendapatkan hasil sebagian responden mengalami penurunan kadar natrium yang bermakna, tetapi dengan waktu latihan hanya 10 menit. Respondennya diberi minum air mineral 10 menit sebelum latihan fisik dilakukan, sedangkan pada penelitian ini, responden dipuasakan sebelum pengukuran kadar natrium dan aktivitas fisik dilakukan. Penurunan ini disebabkan karena pengeluaran keringat saat bermain futsal menyebabkan natrium ikut terbawa keluar tubuh melalui keringat, sehingga semakin besar laju pengeluaran keringat, laju kehilangan natrium juga akan semakin besar. ${ }^{8}$ Jika keluarnya keringat saat aktivitas fisik tidak diimbangi dengan konsumsi cairan yang cukup, maka air yang keluar dari cairan intertisial atau plasma darah ini akan menyebabkan terjadinya peningkatan konsentrasi elektrolit di dalam cairan ekstrasel. $^{2}$

Penelitian oleh $\mathrm{Koc}^{9}$ tentang efek latihan fisik akut terhadap kadar elektrolit darah pada 12 orang laki-laki pemain bola tangan. Latihan fisik yang dilakukan yaitu mengikuti kompetisi liga bola tangan. Hasil penelitian didapatkan bahwa rerata kadar natrium serum sebelum latihan fisik akut $143,5 \mathrm{mEq} / \mathrm{L}$ dan sesudah latihan fisik akut 
141,9 mEq/L. Hal ini menunjukkan bahwa tidak terdapat penurunan bermakna dari kadar natrium serum sesudah latihan fisik akut. $^{9}$

Perubahan status cairan tubuh saat berolahraga atau sedang melakukan latihan fisik disebabkan oleh peningkatan produksi keringat dan asupan cairan ke dalam tubuh yang sedikit. Pemberian cairan pada seseorang saat berolahraga bertujuan untuk mencegah dehidrasi dan mempertahankan keseimbangan cairan tubuh. Biasanya dianjurkan mengonsumsi $500 \mathrm{~mL}$ air 1-2 jam sebelum latihan fisik atau $600 \mathrm{~mL}$ air atau minuman berkarbohidrat 10-15 menit sebelum latihan fisik. Selama latihan fisik sebaiknya minum air $125-150 \mathrm{~mL}$ setiap 10-15 menit. Setiap kehilangan 0,5 kg maka harus digantikan dengan 500 mL cairan. Konsumsi air putih biasa sesudah latihan fisik akan menurunkan konsentrasi natrium plasma dan osmolalitas plasma. ${ }^{10}$

Penelitian ini mempunyai beberapa keterbatasan antara lain dalam jumlah responden yang seharusnya 30 orang, tetapi yang mengikuti penelitian hanya 21 orang karena 3 mengundurkan diri pada waktu penelitian dan 6 tidak mempunyai data dari laboratorium.

\section{SIMPULAN}

Terdapat perbedaan bermakna antara kadar natrium serum sebelum dan sesudah aktivitas fisik intensitas berat pada mahasiswa Fakultas Kedokteran Universitas Sam Ratulangi.

\section{SARAN}

Disarankan untuk mengonsumsi air dan mineral yang cukup saat melakukan aktivitas fisik intensitas berat untuk mempertahankan keseimbangan cairan dan natrium.

Dapat dilakukan penelitian lebih lanjut mengenai faktor-faktor lain yang dapat mempengaruhi kadar elektrolit, terutama natrium.

\section{DAFTAR PUSTAKA}

1. Suprida. Perbandingan tingkat dehidrasi, kadar anti diuretic hormone (ADH) dan karakteristik urine pada aktivitas fisik maksimal dan submaksimal. 2013. [cited 2014 Oct 7]. Available from: http://poltekkespalembang.ac.id/userfil es/files/perbandingan_tingkat_dehidras i,_kadar_anti.pdf

2. Irawan MA. Konsumsi cairan dan olahraga. PsspLabs [serial online]. 2007 [cited 2014 Oct 13]. Available from:

http://www.pssplab.com/journal/02.pdf

3. Gaw A, Murphy MJ, Cowan RA, O'Reilly DS, Stewart MJ, Stepherd J. Keseimbangan air dan natrium. In: Salim N, Yesdelita N, editor edisi bahasa Indonesia. Biokimia Klinis teks bergambar (Edisi 4). Jakarta: ECG, 2012; p.12-21.

4. Wadud MA. Pengaruh aktivitas fisik aerobic dan anaerobic terhadap kadar ADH dan elektrolit darah. 2013. [cited 2014 Oct 13]. Available from: http://poltekkespalembang.ac.id/userfil es/files/pengaruh_aktivitas_fisik_aerob ik_goog.pdf.

5. Corwin EJ. Keseimbangan Elektrolit. In: Yudha EK, Wahyuningsih E, Yulianti D, Karyuni PE, editors. Buku saku patofisiologi (Edisi ke-3). Jakarta: EGC, 2009; p.738.

6. Wahyudi, Ginting S, Siregar C, Yoel C, Pasaribu S, Lubis M. Perubahan kadar natrium dan kalsium serum akibat pemberian glukosa $40 \%$ pada latihan fisik akut. 2005. [cited 2014 Oct 13. Available from: http://saripediatri.idai.or.id/pdfile/10-21.pdf.

7. Lesar TS. Kadar Natrium Serum Pada Latihan Fisik Intensitas Ringan Mahasiswa Fakultas Kedokteran Universitas Sam Ratulangi [Skripsi]. Manado: Universitas Sam Ratulangi, 2014.

8. Irawan MA. Cairan tubuh, elektrolit dan mineral [homepage on the internet]. 2007 [cited 2015 Jan 17]. Available from:

http://www.pssplab.com/journal/01.pdf

9. Koc $\mathbf{H}$. The effect of acute excercises on blood electrolyte values in handball players. Afr J Pharmacol. 2011;4(1):93-7. 
Jurnal e-Biomedik (eBm), Volume 3, Nomor 3, September-Desember 2015

10.Ronald H. Metode rehidrasi usatf sebagai metode alternative pemulihan cairan tubuh. Revitalisasi Penjas Melalui
Pembenahan Citra Paradigmatis Esensi Filosofis serta Struktur Kelembagaan 21-22 Des 2009. Bandung, 2010. 